\title{
Nano-level Monitoring of Yttrium by a Novel PVC-membrane Sensor Based on 2,9-dihydroxy-1,10-diphenoxy-4,7-dithiadecane
}

\author{
Mohammad Hossein Arbab Zavar, ${ }^{*}$ Somayeh Heydari, Gholam Hossein Rounaghi, and Hamid Sadeghian \\ Department of Chemistry, Faculty of Sciences, Ferdowsi University of Mashhad, Mashhad, Iran
}

RECEIVED JULY 7, 2011; REVISED JANUARY 24, 2012; ACCEPTED FEBRUARY 23, 2012

\begin{abstract}
A poly (vinyl chloride)-based membrane of 2,9-dihydroxy-1,10-diphenoxy-4,7-dithiadecane $\left(\mathrm{C}_{20} \mathrm{H}_{26} \mathrm{O}_{4} \mathrm{~S}_{2}\right)$ as a neutral carrier was prepared and investigated as an $\mathrm{Y}^{3+}$-selective electrode. Effects of various plasticizers and anion excluders were studied in detail and improved performance was observed. The best performance was obtained for the membrane sensor having a composition of L: PVC: NPOE: PA in the ratio of 2:30:62:6 (mg). The performance of the membrane was found to be the following: A Nernstian slope of $20.0 \pm 0.2 \mathrm{mV}$ per decade across a broad range $\left(1.0 \times 10^{-9}\right.$ to $\left.1.0 \times 10^{-1} \mathrm{~mol} \mathrm{dm}^{-3}\right)$; a detection limit of $2.14 \times 10^{-10}$ mol dm${ }^{-3}$ between the $\mathrm{pH}=4.5$ and 9.0 ; additionally, the response time was about $15 \mathrm{~s}$; good $\mathrm{Y}^{3+}$ selectivity over a wide variety of other metal ions. The membrane sensor was applied as an indicator electrode in potentiometric titration of fluoride ion and also used for determination of $\mathrm{F}^{-}$ion in tap water and toothpaste samples. (doi: 10.5562/cca1937)
\end{abstract}

Keywords: potentiometry; sensor PVC membrane; 2,9-dihydroxy-1,10-diphenoxy-4,7-dithia decane; ionselective electrode

\section{INTRODUCTION}

Ion selective electrodes (ISEs) for different cations have been widely used with polymeric membranes containing appropriate carriers (i.e., ionophores). These ionophores have been examined so that they could be incorporated to form complexes with metal ion within the membrane. The quest for the new ligands capable of specific and effective molecular recognition of metal ions in carrier assisted membranes or polymeric membranes based on ion selective electrodes (ISEs) are a topic of current interest. Macrocycles are a favoured class of compounds in this area as their complexes have high stability constants, lipophilicity to remain in the membrane phase and sufficient conformational flexibility for rapid ion exchange. ${ }^{1}$ Synthetic macrocycles are a growing class of compounds with varying chemistry, a wide range of different molecular topologies and sets of donor atoms. ${ }^{2-6}$ The chemical properties of macrocyclic complexes can be tuned to force metal ions to adopt unusual coordination geometry. Currently a great deal of attention is being focussed on macrocyclic ligands because they play an important role in many aspects of chemistry, medicine and the chemical industry.

The rare-earth elements (REEs) are distributed in low concentration throughout the earth's crust and are considered slightly toxic. REEs are being increasingly used as an important component in lasers, phosphors, magnetic bubble memory films, refractive index lenses, fiber optics, superconductors, high-intensity lightning, coloured glasses, refining industry and nuclear technology. ${ }^{7}$ In recent years, the monitoring and evaluation of REEs in some biological materials have received increasing attention, from both nutritional and toxicological point of view. ${ }^{8,9}$

Yttrium is an important member of rare-earth family and widely used for various applications. The most important use of yttrium is in making phosphors, such as in the red phosphors in colour TV tubes and in LEDs. ${ }^{10}$ Other uses include the production of electrodes, electronic filters, lasers, superconductors, computer monitors, trichromatic fluorescent lights, temperature sensors, X-ray intensifying screens and various medical applications and also as traces in various materials to enhance their properties. Yttrium is an important element used in atomic reactors for control rods. It is also used in manufacturing of glass, ceramics and in microwave communication equipments. It is used for the production of labeled monoclonal antibodies for tumor therapy studies. ${ }^{11,12}$ Several reagents are reported for the spectrophotometric determination of yttrium(III) cation, but they are not sensitive nor free from interferences. ${ }^{13-19}$

\footnotetext{
* Author to whom correspondence should be addressed. (E-mail: arbab@um.ac.ir)
} 


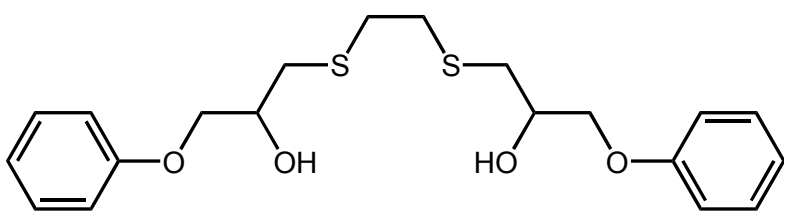

Scheme 1. Structure of macrocyclic ligand 2,9-dihydroxy1,10-diphenoxy-4,7-dithiadecane $\left(\mathrm{C}_{20} \mathrm{H}_{26} \mathrm{O}_{4} \mathrm{~S}_{2}\right)$.

The solvent extraction techniques for the extraction of this metal cation are scarce. ${ }^{20}$ Yttrium(III) cation can not be determined by direct atomic absorption or plasma atomic emission methods, since the ionization causes low response and it is reduced by the presence of mineral acids. Also the flame spectrometric determination of yttrium is not sensitive. ${ }^{21}$

Potentiometric sensors can offer an inexpensive and convenient analysis method of rare-earth ions in solution, provided that acceptable sensitivity and selectivity are achieved. In spite of the successful progress in the design of highly selective ionophores for various metal ions, there are a number of reports on the development of selective ionophores for yttrium and other lanthanide ions with relatively good selectivity and sensitivity. ${ }^{22-24}$ Most of the previous studies include some disadvantages such as high detection limits, narrow dynamic range and serious interfaces. In this work we report a highly selective and sensitive Y(III) sensor based on 2,9-dihydroxy-1,10-diphenoxy-4,7dithiadecane (Scheme 1) for fast monitoring of nanomolar concentration of Y(III) ions.

\section{EXPERIMENTAL}

\section{Reagents and Standard Solutions}

Tetrahydrofuran (THF) (Merck), cerium(III) nitrate (Merck), copper(II) nitrate (BDH), zinc(II) nitrate (Merck), silver nitrate (Merck), cadmium(II) nitrate (Riedel), lead(II) nitrate (BDH), chrominum(III) nitrate $(\mathrm{BDH})$, calcium nitrate (Merck),sodium nitrate (BDH), strontium nitrate (Riedel), magnesium nitrate (Merck), potassium nitrate (Merck), lithium nitrate (Riedel),
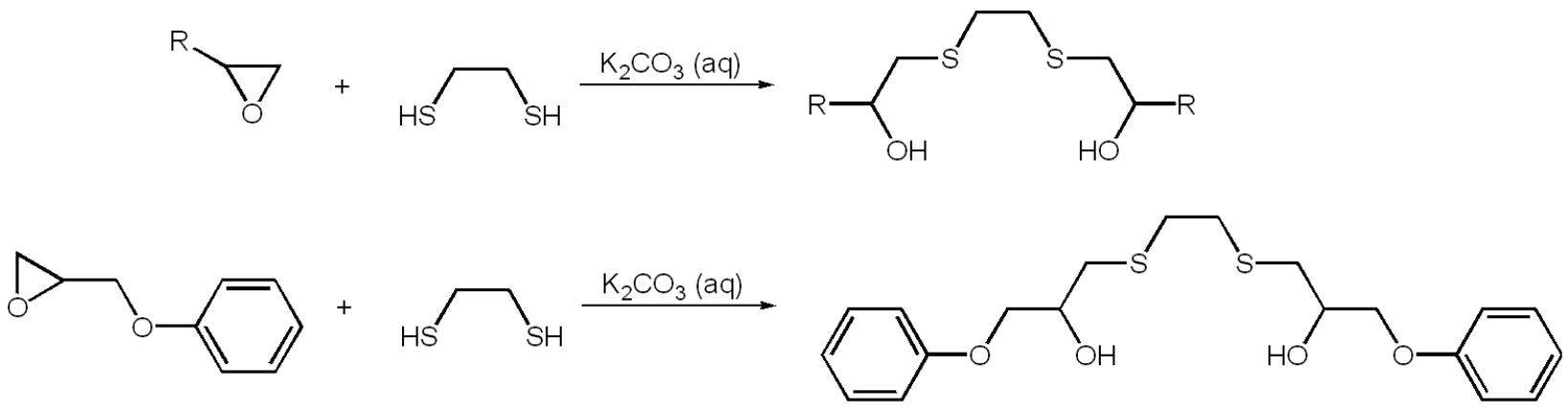

nickel(II) nitrate (Riedel), aluminum nitrate (Riedel), were used without further purification.

Reagent grade dibutyl phthalate (DBP), dioctylphthalate (DOP), o-nitrophenyl octyl ether (NPOE), nithrobenzene (NB), oleic acid (OA), palmitic acid (PA), sodium tetraphenyl borate (NaTPB), ionic liquid (1-ethyl-3-methylimidazolium hexafluorophosphate) and high relative molecular weight PVC (all from Fluka) were used as received. All metal-ion solutions were prepared in doubly distilled water and solutions of different concentrations were made by diluting $0.1 \mathrm{~mol}$ $\mathrm{dm}^{-3}$ stock solutions.

\section{Synthesis of 2,9-dihydroxy-1,10-diphenoxy-4,7-dithia- decane}

Synthetic route for the preparation of acyclic poly ethers is described in Scheme 2. The $\beta, \beta^{\prime}$-dihydroxydithioethers were prepared by the action of two mole equivalents of epoxides with deporotonated dimercaptoethane which was formed by proton abstracting ofcarbonate anion under reflux condition and vigorous stirring. The method used here is a simple, efficientand environmentally friendly procedure with excellent yields, high regioselectivity and need not any organic solvents either for reaction medium or extracting the products. Therefore, the work follows the basic aims which are important to green chemistry. ${ }^{25}$

\section{General Procedure for Ring Opening of Epoxides with Dimercaptoethane}

The ring opening of the starting epoxides was region specific by nucleophilic attack on the terminal carbon atoms affording a secondary diols. The water solubility of epoxides are decreased in the presence of high concentrations of potassium carbonate lead to decrease epoxide ring opening percentage by the protic solvent. Dimercaptoethan is deprotonated by carbonate anion (rather than water deprotonation) lead to formation of water soluble dimercaptid anion, which can react with epoxides in the boundary surface of aqueous and organic phase. This is a suitable condition of the $\mathrm{S}_{\mathrm{N}} 2$ mechanism resulted nucleophilic attack on low substituted site.

Scheme 2. Synthetic route for preparation of acyclic polyethers. 
Obviously, the ring opening of epoxides afforded corresponding dihydroxy dithioethers as a mixture of isomeric diastreomers. ${ }^{29}$ It was notable that in low concentrations of potassium carbonate, the formation of mono substituted ethandiols instead of corresponding $\beta, \beta^{\prime}-$ dihydroxy-dithioethers, was increased. This was obvious when the results were checked by TLC and sodium metaperiodate-benzidine test of 1,2-diols.

To a solution of potassium carbonate $(50 \mathrm{~g}, 350$ mmol) in water $\left(65 \mathrm{~cm}^{3}\right)$ was added dimercaptoethane $\left(13.5 \mathrm{~cm}^{3}, 160 \mathrm{mmol}\right)$ followed by epoxide (300 mmol). The mixture was refluxed in oil bath while stirring vigorously. The completion of reaction was checked by TLC (silica gel $60 \mathrm{~F}_{254}$, benzene/ethylacetate, $\varphi=50 \%$ ). After completion, the mixture was cooled and the precipitated products, were filtered, washed with water $\left(3 \times 50 \mathrm{~cm}^{3}\right)$ and dried in an oven at $50-55{ }^{\circ} \mathrm{C}$ for 4 h. m.p. $79{ }^{\circ} \mathrm{C},{ }^{1} \mathrm{H}$ NMR $\left(\mathrm{CCl}_{4}\right) \delta /$ ppm: 2.39 (bs, 2H, OH), 2.71 (dd, 2H, $\left.J_{1}=15.5 \mathrm{~Hz}, J_{2}=7.2, \mathrm{CHCH}_{2} \mathrm{~S}\right), 2.79\left(\mathrm{dd}, 2 \mathrm{H}, J_{1}=\right.$ $\left.17.8 \mathrm{~Hz}, J_{2}=4.2, \mathrm{CHCH}_{2} \mathrm{~S}\right), 2.85\left(\mathrm{~s}, 4 \mathrm{H}, \mathrm{SCH}_{2} \mathrm{CH}_{2} \mathrm{~S}\right)$, $4.04\left(\mathrm{dd}, 2 \mathrm{H}, J_{1}=15.8 \mathrm{~Hz}, J_{2}=6.2, \mathrm{CH}_{2} \mathrm{O}\right), 4.12(\mathrm{~m}$, $2 \mathrm{H}, \mathrm{CHOH}), 4.15\left(\mathrm{dd}, 2 \mathrm{H}, J_{1}=13.7 \mathrm{~Hz}, J_{2}=4.1\right.$, $\left.\mathrm{CH}_{2} \mathrm{O}\right), 6.84-7.38(\mathrm{~m}, 10 \mathrm{H}, \mathrm{Ph}) ;{ }^{13} \mathrm{C} \mathrm{NMR}\left(\mathrm{CCl}_{4}\right)$ $\delta$ / ppm: $33.10\left(\mathrm{SCH}_{2} \mathrm{CH}_{2} \mathrm{~S}\right), 35.80\left(\mathrm{CHCH}_{2} \mathrm{~S}\right), 69.91$ $(\mathrm{CHOH}), 70.92\left(\mathrm{CH}_{2} \mathrm{O}\right), 114.90(2,6-\mathrm{Ph}), 121.09$ (4$\mathrm{Ph}), 120.74$ (3,5-Ph), 159.23 (1-Ph); EI-MS m / z: 394 $\left(\mathrm{M}^{+}\right), 287\left(\mathrm{M}^{+}-107\right), 243\left(\mathrm{M}^{+}-151\right), 211\left(\mathrm{M}^{+}-183\right)$, $77\left(\mathrm{C}_{6} \mathrm{H}_{5}^{+}, 100 \%\right){ }^{26}$

Anal. Calcd. mass fractions of elements, $w / \%$, for $\mathrm{C}_{20} \mathrm{H}_{26} \mathrm{O}_{4} \mathrm{~S}_{2}\left(M_{\mathrm{r}}=394.55\right)$ are: $\mathrm{C} 60.88, \mathrm{H} 6.64, \mathrm{~S} 16.25$; found: C 61.13, H 6.72, S 16.07.

\section{Apparatus and Potential Measurement}

All potential measurements were carried out using the following cell assembly:

$\mathrm{Ag}-\mathrm{AgCl} / \mathrm{KCl}$ (sat)/internal solution $1.0 \times 10^{-3} \mathrm{~mol} \mathrm{dm}^{-3}$ $\mathrm{Y}\left(\mathrm{NO}_{3}\right)_{3} / \mathrm{PVC}$ membrane/test solution $/ / \mathrm{Ag}-\mathrm{AgCl} / \mathrm{KCl}$ (sat)

All the potential measurements were carried out with a digital $\mathrm{pH} / \mathrm{Ion}$ meter, model 692 Metrohm, at $25.0 \pm 0.1{ }^{\circ} \mathrm{C}$. The activities were calculated according to the Debye-Huckel procedure. ${ }^{27}$ Standard $\mathrm{Y}\left(\mathrm{NO}_{3}\right)_{3}$ solutions were obtained by gradual dilution of $0.1 \mathrm{~mol}$ $\mathrm{dm}^{-3} \mathrm{Y}\left(\mathrm{NO}_{3}\right)_{3}$ solution. The solutions were stirred and potential readings recorded when they reached a steady state values. A glass $\mathrm{Ag}-\mathrm{AgCl}$ combination electrode was used for $\mathrm{pH}$ measurements. The electronic absorption spectra of lanthanum, ligand and the formed complex were recorded in acetonitrile solvent in the region of 200-700 nm using an Agilent UV-Vis spectrophotometer and a quartz cell of $1.0 \mathrm{~cm}$ path length.

\section{Electrode Preparation}

The general procedure to prepare the PVC membrane was to mix thoroughly $30 \mathrm{mg}$ of powdered PVC, $62 \mathrm{mg}$ of plasticizer NPOE, $6 \mathrm{mg}$ of additive PA, and $2 \mathrm{mg}$ of ionophore in a glass dish of $2 \mathrm{~cm}$ diameter. The mixture was then completely dissolved in $3 \mathrm{~mL}$ of THF. The solvent was evaporated slowly until an oily concentrated mixture was obtained. A Pyrex tube ( $2.5 \mathrm{~mm}$ o.d.) was dipped into the mixture for $10 \mathrm{~s}$ so that a transparent membrane was formed. The tube was then pulled out from the mixture and kept at room temperature for $24 \mathrm{~h}$. The tube was filled with internal filling solution $\left(1.0 \times 10^{-3}\right.$ mol dm $\left.{ }^{-3} \mathrm{Y}\left(\mathrm{NO}_{3}\right)_{3}\right)$. The electrode was finally conditioned for $7 \mathrm{~h}$ in a $1.0 \times 10^{-3} \mathrm{~mol} \mathrm{dm}^{-3}$ solution of $\mathrm{Y}\left(\mathrm{NO}_{3}\right)_{3}$.

\section{RESULTS AND DISCUSSION}

\section{Complexation Study of $\mathrm{C}_{20} \mathrm{H}_{26} \mathrm{O}_{4} \mathrm{~S}_{2}$ Ligand With $\mathrm{Y}^{3+}$}

Trivalent lanthanide ions have the outer shell electronic configuration as $[\mathrm{Xe}] 4 \mathrm{f}^{(1-14)} 5 \mathrm{~d}^{1} 6 \mathrm{~s}^{2}$. The bonds between Yttrium ion and the macrocyclic $\mathrm{C}_{20} \mathrm{H}_{26} \mathrm{O}_{4} \mathrm{~S}_{2}$ ionophore are mainly ion-dipole and non-directional. Thus, in order to obtain a clue about the stability and selectivity of the complex of $\mathrm{C}_{20} \mathrm{H}_{26} \mathrm{O}_{4} \mathrm{~S}_{2}$ with Yttrium ion, conductometric titration in an acetonitrile solution, at $25.0 \pm 0.05{ }^{\circ} \mathrm{C}$, was performed. Figure 1 shows the changes in the conductance of $20 \mathrm{~cm}^{3}$ of $1 \times 10^{-4} \mathrm{~mol}$ $\mathrm{dm}^{-3}$ solution of $\mathrm{Y}^{3+}$, by the addition of a $2 \times 10^{-3} \mathrm{~mol}$ $\mathrm{dm}^{-3}$ of $\mathrm{C}_{20} \mathrm{H}_{26} \mathrm{O}_{4} \mathrm{~S}_{2}$ in acetonitrile. As is obvious from Figure 1, addition of $\mathrm{C}_{20} \mathrm{H}_{26} \mathrm{O}_{4} \mathrm{~S}_{2}$ ligand to $\mathrm{Y}^{3+}$ solution shows an increase in molar conductivity with an increase in ligand concentration. This indicates that the complex is more mobile than free solvated $\mathrm{Y}^{3+}$ cation in acetonitrile. It is evident from Figure 1 that the slope of the corresponding molar conductivity vs $\left[\mathrm{C}_{20} \mathrm{H}_{26} \mathrm{O}_{4} \mathrm{~S}_{2}\right] /$ $[\mathrm{Y}]^{3+}$ mole ratio changes at the point where the ligand to cation mole ratio is about 2 , which is an evidence for formation of a relatively stable 1:2 complex between $\mathrm{C}_{20} \mathrm{H}_{26} \mathrm{O}_{4} \mathrm{~S}_{2}$ and the $\mathrm{Y}^{3+}$. The conductometric results that

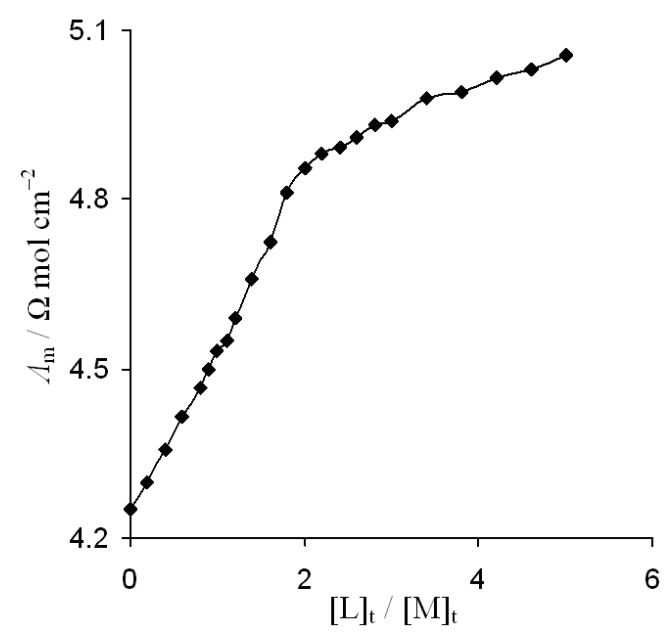

Figure 1. Molar conductance-mole ratio plots for the complexation of $\mathrm{C}_{20} \mathrm{H}_{26} \mathrm{O}_{4} \mathrm{~S}_{2}$ with Yttrium cation in acetonitrile at $25^{\circ} \mathrm{C}$. 
Table 1. Optimization of membrance ingredients

\begin{tabular}{|c|c|c|c|c|c|c|c|}
\hline \multirow{2}{*}{ No. } & \multicolumn{4}{|c|}{$w / \%$} & \multirow{2}{*}{$\begin{array}{c}\text { Slope / } \\
\mathrm{mV} \mathrm{decade}^{-1}\end{array}$} & \multirow{2}{*}{$\begin{array}{l}\text { Linear range / } \\
\text { mol dm}^{-3}\end{array}$} & \multirow{2}{*}{$\begin{array}{l}\text { Detection limit } \\
\mathrm{mol} \mathrm{dm}^{-3}\end{array}$} \\
\hline & PVC & Plasticizer & Ionophore & Additive & & & \\
\hline 1 & 30 & 62 (NPOE) & 2 & $6(\mathrm{PA})$ & $20.0 \pm 0.2$ & $1.0 \times 10^{-9}-1.0 \times 10^{-1}$ & $2.14 \times 10^{-10}$ \\
\hline 2 & 30 & 61.5 (NPOE) & 3 & $5.5(\mathrm{PA})$ & $16.6 \pm 0.4$ & $1.0 \times 10^{-5}-1.0 \times 10^{-1}$ & $3.98 \times 10^{-6}$ \\
\hline 3 & 30 & 62.5 (NPOE) & 1.5 & $6(\mathrm{PA})$ & $19.9 \pm 0.3$ & $1.0 \times 10^{-5}-1.0 \times 10-1$ & $3.55 \times 10^{-6}$ \\
\hline 4 & 30 & 61 (NPOE) & 2 & $7(\mathrm{PA})$ & $27.6 \pm 0.2$ & $1.0 \times 10^{-6}-1.0 \times 10^{-3}$ & $3.01 \times 10^{-7}$ \\
\hline 5 & 30 & 61.5 (NPOE) & 2.5 & 6 (NaTPB) & $5.7 \pm 0.2$ & $1.0 \times 10^{-7}-1.0 \times 10^{-2}$ & $4.5 \times 10^{-8}$ \\
\hline 6 & 30 & 62 (NPOE) & 2 & 6 (NaTPB) & $6.1 \pm 0.1$ & $1.0 \times 10^{-8}-1.0 \times 10^{-2}$ & $9.0 \times 10^{-9}$ \\
\hline 7 & 30 & 61.5 (NPOE) & 3 & 5.5 (NaTPB) & $8.8 \pm 0.1$ & $1.0 \times 10^{-6}-1.0 \times 10^{-3}$ & $3.09 \times 10^{-7}$ \\
\hline 8 & 30 & 62 (NPOE) & 2 & $6(\mathrm{OA})$ & $7.8 \pm 0.2$ & $1.0 \times 10^{-5}-1.0 \times 10^{-2}$ & $3.09 \times 10^{-6}$ \\
\hline 9 & 30 & 62 (NPOE) & 2 & $6(\mathrm{IL})^{(\mathrm{a})}$ & $14.0 \pm 0.3$ & $1.0 \times 10^{-3}-1.0 \times 10^{-1}$ & $2.14 \times 10^{-4}$ \\
\hline 10 & 30 & 61.5 (NPOE) & 3 & $5.5(\mathrm{IL})^{(\mathrm{a})}$ & $13.0 \pm 0.3$ & $1.0 \times 10^{-5}-1.0 \times 10^{-3}$ & $2.57 \times 10^{-6}$ \\
\hline 11 & 30 & 62 (DBP) & 2 & $6(\mathrm{PA})$ & $30.1 \pm 0.4$ & $1.0 \times 10^{-5}-1.0 \times 10^{-1}$ & $3.71 \times 10^{-6}$ \\
\hline 12 & 30 & 61.5 (DBP) & 3 & $5.5(\mathrm{PA})$ & $19.1 \pm 0.2$ & $1.0 \times 10^{-6}-1.0 \times 10^{-2}$ & $3.8 \times 10^{-7}$ \\
\hline 13 & 30 & 62 (DBP) & 2 & 6 (NaTPB) & $7.5 \pm 0.3$ & $1.0 \times 10^{-4}-1.0 \times 10^{-2}$ & $2.63 \times 10^{-5}$ \\
\hline 14 & 30 & 62 (DOP) & 2 & $6(\mathrm{PA})$ & $18.9 \pm 0.2$ & $1.0 \times 10^{-5}-1.0 \times 10^{-1}$ & $3.23 \times 10^{-6}$ \\
\hline 15 & 30 & $62(\mathrm{NB})$ & 2 & $6(\mathrm{PA})$ & $24.0 \pm 0.2$ & $1.0 \times 10^{-7}-1.0 \times 10^{-1}$ & $5.0 \times 10^{-8}$ \\
\hline 16 & 30 & $61.5(\mathrm{NB})$ & 3 & $5.5(\mathrm{PA})$ & $17.3 \pm 0.1$ & $1.0 \times 10^{-8}-1.0 \times 10^{-1}$ & $1.0 \times 10^{-9}$ \\
\hline
\end{tabular}

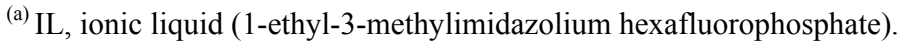

obtained revealed that, 2,9-dihydroxy-1,10-diphenoxy4,7-dithiadecane could be used as a highly selective ionophore for the preparation of $\mathrm{Y}^{3+}$ ion-selective membrane electrode.

\section{Effect of Membrane Composition}

It is well known that some important features of the PVC-based membranes, such as the nature and amount of the ionophore, the properties of the plasticizer, the plasticizer/ PVC ratio and especially the nature of the additives used, significantly influence the sensitivity and selectivity of the ion-selective electrodes. ${ }^{28,29}$ Thus, different aspects of preparation of membranes based on $\mathrm{C}_{20} \mathrm{H}_{26} \mathrm{O}_{4} \mathrm{~S}_{2}$ were optimized and the results are given in Table 1. In order to improve the performance of the membrane, different plasticizers (i.e., DBP, DOP, $o$-NPOE and NB) and additives (i.e., NaTPB, PA, OA and an ionic liquid 1-ethyl-3-methylimidazolium hexafluorophosphate) were studied. It is reported that the selectivity and working concentration range of membrane sensors are affected by the nature and amount of the plasticizer used. This is due to the influence of the plasticizer on the dielectric constant of the membrane phase, the mobility of the ionophore molecules and the state of ligands. As is seen from Table 1, among the four different plasticizers used, NPOE resulted in the best sensitivity.

It is well known that the presence of lipophilic additives sites in a cation-selective membrane electrode not only improves the response behavior and selectivity of electrode, but also increases the sensitivity of the membrane, especially where the extraction capability is poor. $^{30.31}$ The use of ionic additives such as different tetraphenylborate salts and its more lipophilic derivative, also fatty acids such as oleic acid as lipophilic additives is widely reported in the preparation of different ion-selective electrodes. In this study the effect of palmetic acid, oleic acid, sodium tetraphenyl borate, and ionic liquid (1-ethyl-3-methylimidazolium hexafluorophosphate), as an additive on the response of membrane were investigated. From the data given in Table 1, it is immediately obvious that the nature and amount of additive influences the performance characteristics of the membrane sensor significantly. As shown in this table, the slopes and the linear range become better in the presence of palmitic acid (a long-chain fatty acid) additive. The palmitic acid has been used for construction of some potentiometric biosensors, ${ }^{32}$ but in this work, we used it as a very suitable additive in PVC matrix of the ion selective membrane electrode. Palmitic acid is probably interposed between the matrix (62\% NPOE, $30 \%$ PVC) and $\mathrm{C}_{20} \mathrm{H}_{26} \mathrm{O}_{4} \mathrm{~S}_{2}$ to facilitate more effective binding and it may also prevent that the active site of the ionophore to be located in deep position of the membrane.

The effect of relative amounts of 2,9-dihydroxy1,10-diphenoxy-4,7-dithiadecane on the response function of membrane was investigated (Table 1). $2 \mathrm{mg}$ of the ionophore was chosen as the optimum amount of ionophore in construction of the PVC membrane electrode. Further addition of ionophore, however, resulted 


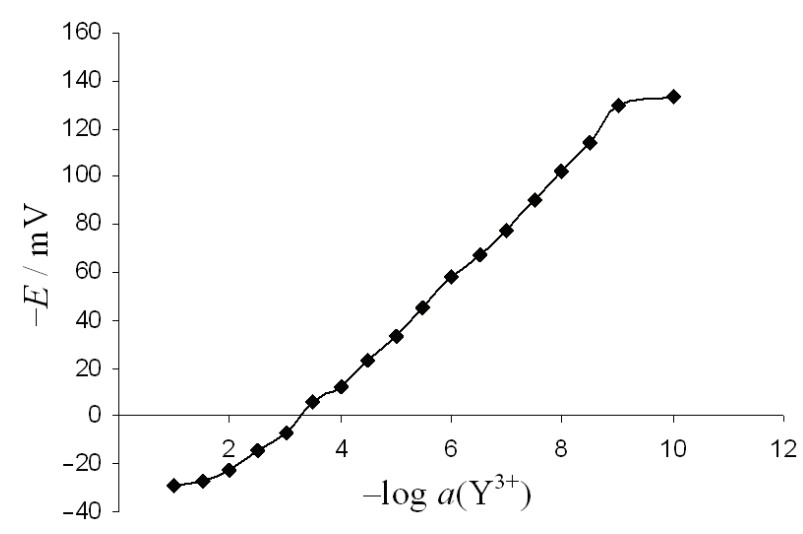

Figure 2. Calibration curve of Yttrium electrode based on $\mathrm{C}_{20} \mathrm{H}_{26} \mathrm{O}_{4} \mathrm{~S}_{2}$.

in some decreases in the response of the electrode, most probably due to inhomogenity and possible saturation of the membrane.

Optimum conditioning time for the membrane sensor in a $1.0 \times 10^{-3} \mathrm{~mol} \mathrm{dm}{ }^{-3} \mathrm{Y}^{3+}$ solution was obtained to be $7 \mathrm{~h}$. Then, the electrode generates stable potentials when placed in contact with $\mathrm{Y}^{3+}$ solution.

\section{Calibration Curve and Statistical Data}

The plot of EMF vs $-\log a\left(\mathrm{Y}^{3+}\right)$ shown in Figure 2, indicates that the sensor has a Nernstian behavior over a wide concentration ranges from $1.0 \times 10^{-9}$ to $1.0 \times 10^{-1}$ mol dm${ }^{-3}$ of Yttrium(III) cation. The respective slopes of the resulting calibration graphs for electrode are 20.0 $\pm 0.2 \mathrm{mV}$ decade $^{-1}$ and limit of detection (LOD) was found to be $2.14 \times 10^{-10}$.

\section{Effect of pH}

In order to study the effect of $\mathrm{pH}$ on the performance of the sensor, the potentials were determined at two concentrations $\left(1.0 \times 10^{-4}\right.$ and $\left.1.0 \times 10^{-3} \mathrm{~mol} \mathrm{dm}^{-3}\right)$ of $\mathrm{Y}^{3+}$ as a function of $\mathrm{pH}$. The $\mathrm{pH}$ of solutions was adjusted

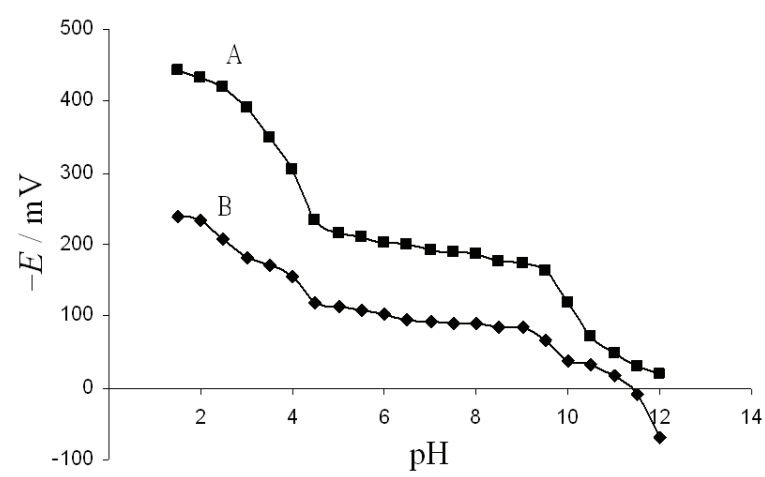

Figure 3. Effect of $\mathrm{pH}$ of $1.0 \times 10^{-4} \mathrm{~mol} \mathrm{dm}^{-3}$ (A) and $1.0 \times$ $10^{-3} \mathrm{~mol} \mathrm{dm}^{-3}$ (B) of test solutions on the potential response of Y(III) ion-selective electrode. by the addition of $\mathrm{NaOH}$ and $\mathrm{HNO}_{3}$. The obtained results shown in Figure 3 indicate that the potential remains approximately constant over $\mathrm{pH}=4.5$ to $\mathrm{pH}=9$. At higher $\mathrm{pH}$ values, the potential decreased due to the formation of Yttrium hydroxide in solution; and at lower $\mathrm{pH}$ values, the potential increased, indicating that the electrode also responds to hydrogen ion.

\section{Static and Dynamic Response Times of the Electrode}

Response time is one of the most important factors for analytical applications of selective electrodes. In order to evaluate the practical static response time of the electrode, the average time required to achieve a potential within $\pm 1 \mathrm{mV}$ of the final steady-state potential was measured by recording the potential-time plots of three different concentrations of $\mathrm{Y}^{3+}$ and the results are shown in Figure 4a. The results clearly indicate that, in all cases, the electrode exhibits a constant and stable potential within $15 \mathrm{~s}$. Moreover, the practical dynamic re-
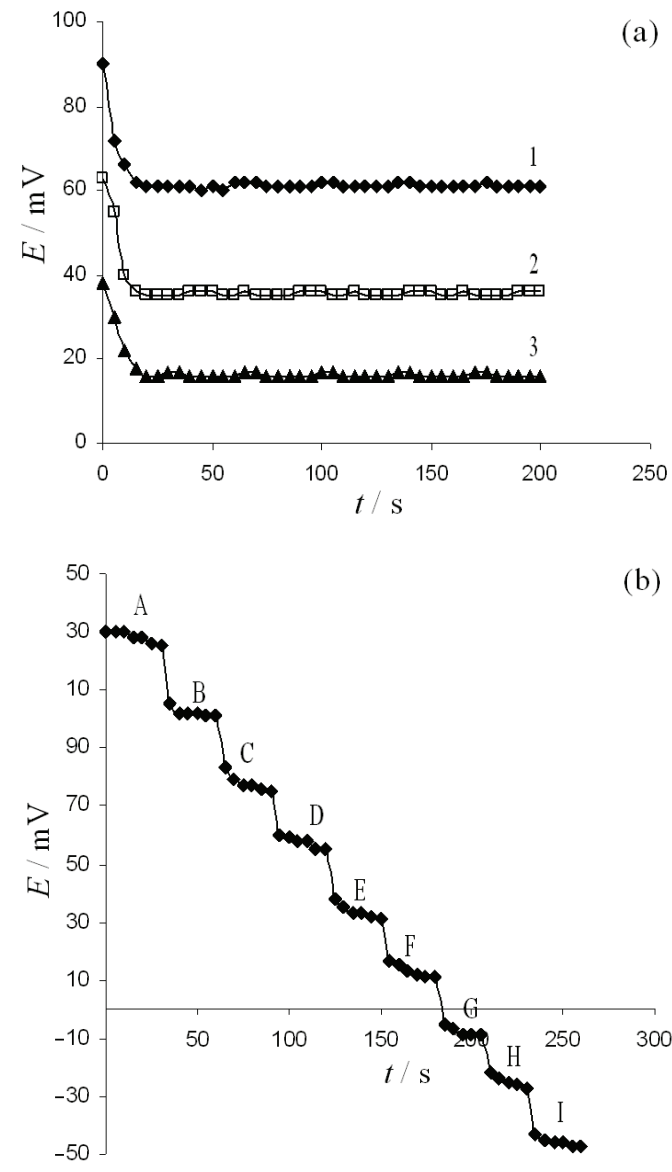

Figure 4. (a) Static potential-time plots of three different Yttrium concentrations $\left(\mathrm{mol} \mathrm{dm}{ }^{-3}\right)$ : (1) $1.0 \times 10^{-4}$, (2) $1.0 \times$ $10^{-3}$, and (3) $1.0 \times 10^{-2}$. (b) Dynamic response time of the Yttrium sensor with step changes in the $\mathrm{Y}^{3+}$ concentration $\left(\mathrm{mol} \mathrm{dm}{ }^{-3}\right)$ : (A) $1.0 \times 10^{-9}$, (B) $1.0 \times 10^{-8}$, (C) $1.0 \times 10^{-7}$, (D) $1.0 \times 10^{-6}$, (E) $1.0 \times 10^{-5}$, (F) $1.0 \times 10^{-4}$, (G) $1.0 \times 10^{-3},(\mathrm{H})$ $1.0 \times 10^{-2}$ and (I) $1.0 \times 10^{-1}$. 
Table 2. Selectivity coefficients of various interfering ions for the $\mathrm{Y}^{3+}$ ISE

\begin{tabular}{cc}
\hline Cations & Selectivity coefficient \\
\hline $\mathrm{Cu}^{2+}$ & $3.5 \times 10^{-4}$ \\
$\mathrm{Ni}^{2+}$ & $4.0 \times 10^{-4}$ \\
$\mathrm{~K}^{+}$ & $3.9 \times 10^{-4}$ \\
$\mathrm{Ag}^{+}$ & $3.2 \times 10^{-3}$ \\
$\mathrm{Zn}^{2+}$ & $4.8 \times 10^{-4}$ \\
$\mathrm{Na}^{+}$ & $1.7 \times 10^{-3}$ \\
$\mathrm{Li}^{+}$ & $2.4 \times 10^{-3}$ \\
$\mathrm{Sr}^{2+}$ & $4.8 \times 10^{-4}$ \\
$\mathrm{~Pb}^{2+}$ & $5.4 \times 10^{-4}$ \\
$\mathrm{Mg}^{2+}$ & $1.9 \times 10^{-4}$ \\
$\mathrm{Ca}^{2+}$ & $2.6 \times 10^{-4}$ \\
$\mathrm{Al}^{3+}$ & $<1.0 \times 10^{-6}$ \\
\hline
\end{tabular}

sponse time of the electrode was recorded by immediate changing of $\mathrm{Y}^{3+}$ concentration from low-to-high over a concentration range from $1.0 \times 10^{-9}$ to $1.0 \times 10^{-1} \mathrm{~mol}$ $\mathrm{dm}^{-3}$ and the results are shown in Figure $4 \mathrm{~b}$. As it can be seen, by an increase in the concentration of the analyte, the potential changes very rapidly $(<10 \mathrm{~s})$ and the electrode reaches its equilibrium response and remains stable with an elapse of time.

\section{Evaluation of Selectivity Coefficients}

The potentiometric selectivity coefficients, which reflect the relative response of the membrane sensor toward the primary ion over the ions present in the solutions, perhaps are the most important characteristics of an ion-selective electrode. To investigate the selectivity of the proposed membrane electrode, its potential responses were investigated in the presence of various interfering foreign cations using the separate solution method (SSM).

In the SSM method, the potential of a cell comprising a reference electrode and an ion-selective electrode is measured with each of two separate solutions, one containing the ion of interest $\mathrm{i}$ with the activity of $a_{i}$ (but not $j$ ) and the other containing an interfering ion $j$ with the activity of aj (but not $i$ ) at the same activity of $a_{i}=a_{j}$. If the measured values are $E_{i}$ and $E_{j}$, the value of selectivity coefficient $K_{i, j}^{\text {Pot }}$ can be calculated as: $:^{33,34}$

$$
\log K_{i, j}^{\mathrm{Pot}}=\frac{z_{i} F\left(E_{j}-E_{i}\right)}{2.303 R T}+\left(1-\frac{z_{i}}{z_{j}}\right) \log a_{i}
$$

where $z_{i}$ and $z_{j}$ are the charges on ions $i$ and $j$, respectively. It should be noted that this method is recommended if the electrode possesses a Nernstian response. The resulting $K_{i, j}^{\text {Pot }}$ values thus obtained for the proposed $\mathrm{Y}^{3+}$-selective electrode are summarized in Table 2. As

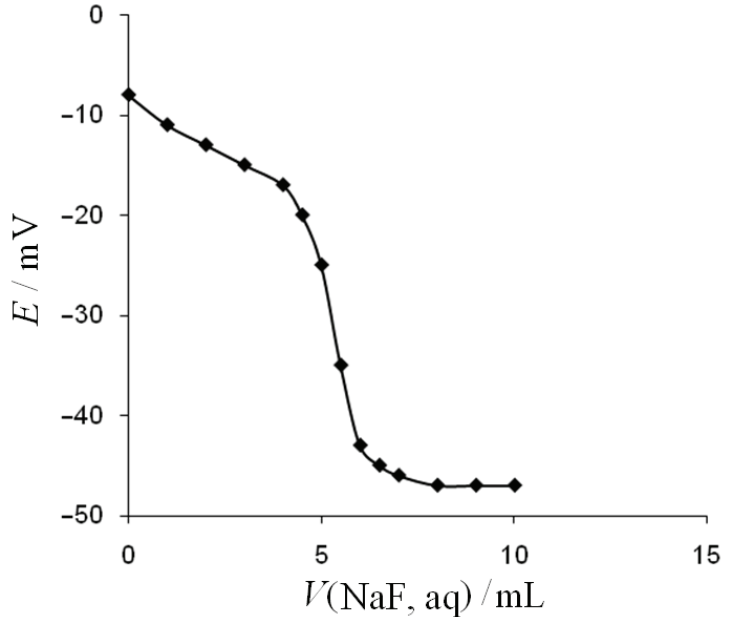

Figure 5. Potentiometric titration curve of $20 \mathrm{~cm}^{3} 1.0 \times 10^{-3}$ mol dm ${ }^{-3} \mathrm{Y}^{3+}$ solution with $0.01 \mathrm{~mol} \mathrm{dm}^{-3}$ fluoride.

seen, the alkali, alkaline earth and transition metal ions do not significantly disturb the functioning of the proposed $\mathrm{Y}^{3+}$ ion selective membrane electrode.

\section{Analytical Applications}

The proposed $\mathrm{Y}^{3+}$ selective electrode was found to work well under laboratory conditions. A typical potentiometric titration curve for titration of yttrium(III) cation $\left(20 \mathrm{~cm}^{3}\right.$ of $\left.1 \times 10^{-3} \mathrm{~mol} \mathrm{dm}^{-3}\right)$ with a solution of sodium flouride $\left(0.01 \mathrm{~mol} \mathrm{dm}^{-3}\right)$ is shown in Figure 5 . The end point of the titration and the concentration of yttrium(III) cation in solution can be determined potentiometrically by using this ion selective electrode. The present electrode has been successfully used for the determination of fluoride ion in aqueous solutions including tap water and in the pharmaceutical preparations such as toothpaste. In each case, the $\mathrm{pH}$ value was adjusted to 5.0 (using a TISAB solution) and a successful titration was carried out. The determination of fluoride concentration was performed by the standard addition method. In this work, before the titration, the potential of the ISE for $10 \mathrm{~cm}^{3}$ of the sample is measured. Then the standard solutions of fluoride ion are added and the potential is measured. The electrode potential is related to the logarithm of the concentration of the fluoride ion by the Nernst equation. We also determined the

Table 2. Results of the determination of the fluoride in the different samples

\begin{tabular}{lcc}
\hline Cations & $\begin{array}{c}\text { Fluoride electrode } \\
\text { mol dm }^{-3} /\end{array}$ & $\begin{array}{c}\text { Found ISE }^{(\mathrm{b})} / \\
\mathrm{mol} \mathrm{dm}^{-3}\end{array}$ \\
\hline Tap water & $4.49 \times 10^{-4} \pm 0.05$ & $4.61 \times 10^{-4} \pm 0.03$ \\
Toothpaste & $1.85 \times 10^{-4} \pm 0.03$ & $1.96 \times 10^{-4} \pm 0.02$ \\
\hline
\end{tabular}

(a) Solid state fluoride electrode.

(b) Proposed yttrium sensor. 
fluoride ion concentration in a sample solution with a fluoride ion selective electrode as a reference method. The results are compared in Table 3. As is evident in this Table, there is a good agreement between the results obtained with these two ion selective electrodes.

\section{CONCLUSION}

A $o$-NPOE mediated PVC-membrane containing 2,9dihydroxy-1,10-diphenoxy-4,7-dithiadecane $\left(\mathrm{C}_{20} \mathrm{H}_{26} \mathrm{O}_{4} \mathrm{~S}_{2}\right)$, as a suitable ionophore, revealed the best response characteristics with a Nernstian behavior over a wide concentration range from $1.0 \times 10^{-9}$ to $1.0 \times 10^{-1} \mathrm{~mol} \mathrm{dm}^{-3}$ for the $\mathrm{Y}^{3+}$, with a fast response time of $10 \mathrm{~s}$. The results showed that palmitic acid is a suitable lipophilic additive for the electrode construction. The main advantages of this constructed yttrium(III) cation electrode are the simplicity of its preparation, short conditioning time, fast response time, wide dynamic range, low detection limit, low cost, Nernstian behavior, and fairly good selectivity. Another major advantage of the present ptentiometric sensor, concerns its application. The electrode permits the measurement of the fluoride ion in different real samples such as pharmaceutical products and water without prior separation steps.

Acknowledgements. The authors acknowledge the support of this work by Ferdowsi University of Mashhad, Mashhad, Iran.

\section{REFERENCES}

1. H. Tsukube, Talanta 40 (1993) 1313-1324

2. K. Y. Choi, H. Y. Lee, B. Park, J. H. Kim, J. Kim, M. W. Kim, J. W. Ryu, M. Suh, and I.-H Suh Polyhedron 20 (2001) 2003-2009.

3. T. W. Hambley, L. F. Lindoy, J. R. Reimers, P. Turner, W. Wei, and A. N. W. Cooper, J. Chem. Soc., Dalton Trans. 5 (2001) 614-620.

4. E. Q. Gao, H. Y. D. Z. Liao, Z. H. Jiang, and S. P. Yan, Polyhedron 21 (2002) 359-364.

5. R. R. Fenton, R. Gauci, P. C. Junk, L. F. Lindoy, R. C. Luckay, and G.V. Meehan, J. Chem. Soc., Dalton Trans. 10 (2002) 2185-2193.

6. S. Chandra and K. Gupta, Transit. Metal Chem. 27 (2002) 196-199.

7. K. A. Gschneidner and L. Erying, Handbook on Physics and Chemistry of Rare Earths, North Holland Publishing Co., Amsterdam, 1979.
8. R. E. Kirk and D. F. Othmes, Encyclopedia of Chemical Technology 19 (1928) 851-863.

9. W. Yongxing, W. Xiaorong, and H. Zichum, Bull. Environ. Contamin. Toxicol. 64 (2000) 611-616.

10. B. A. Morton, B. G. Bealty, A. D. Mison, P. M. Wanek, and J. D. Beatly, Cancer Res. 50 (1990) 1008-1010.

11. J. M. Esteban, D. M. Hyams, B. G. Beatly, B. Merchant, and J. D. Beatly, Cancer Res. 50(1990) 989-992.

12. L. C. Washburn, T. T. H. Sun, Y. C. C. Lee, B. L. Byrd, E. C. Hollway, J. E. Crook, J. B. Stubbs, , M. G. Stabin, M. W. Brechbiel, O. A. Gansow, and Z. Steplewski, Nucl. Med. Biol. 18 (1991) 313-321.

13. J. J. Christensen, D. J. Eatough, and R. M. Izatt, Chem. Rev. 74 (1974) 351-384

14. R. M. Izatt and J. J. Christensen (Eds.), Academic Press, New York, 1978, p25.

15. R. M. Izatt and J. J. Christenses, Progress in Macrocyclic chemistry, Wiley Interscience, New York, 1979.

16. W. J. MecDowell, G. N. Case, J. A. M. C. Donough, and R. A. Bartsch, Anal. Chem. 64 (1992) 3013-3017.

17. V. V. Yakshin and O. M. Viokova, Radiokhimiya 34 (1992) 68-71.

18. J. N. Mathur and G. R. Choppin, Solvent Extr. Ion Exch. 11 (1993) 1-18.

19. D. J. Wood, S. Flshani, H. S. Du, N. R. Natale, and C. M. Wai, Anal. Chem. 7 (1993) 312-316.

20. H. Onishi and C. V. Bank's, Talanta 10 (1963) 399-406.

21. J. G. Sen Gupta, Talanta 23 (1976) 343-348.

22. V. K. Gupta, S. Jain, and S. Chandra, Anal. Chim. Acta 486 (2003) 199-207.

23. S. K. Mittal, S. K. A. Kumar, and H. K. Sharma, Talanta 62 (2004) 801-805.

24. M. Shamsipur, M. Yousefi, M. Hosseini, and M. R. Ganjali, Anal. Chem. 74 (2002) 5538-5543.

25. J. H. Clark, Green Chem. 8 (2006) 17-21.

26. S. M. Sayedi, H. Sadeghian, and M. Rezai, Phosphorus, Sulfur, Silicon 182 (2007) 1709-1716.

27. S. Kamata, A. Bhale, and Y. Fukunaga, Anal. Chem. 60 (1988) 2464-2467.

28. M. R. Ganjali, R. Kiani, M. Yousefi, and Faal-rastegar, Anal. Lett. 36 (2003) 2123-2137.

29. M. Shamsipur, M. Javanbakht and A. R. Hassaninejad, Electroanalysis 15 (2003) 1251-1259.

30. D. Ammann, E. Pretsch, W. Simon, E. Lindler, A. Bezegh and E. Pungor, Anal. Chim. Acta 171 (1985) 119-129.

31. M. Huser, P. M. Gehrig, W. E. Morf, W. Simon, E. Lindler, J. Jeney, K. Toth, and E. Pungo, Anal. Chem. 63 (1991) 1380-1386.

32. E. Karakus, S. Pekyardimci, and E. Kilic, Process Biochem. 41 (2006) 1371-1377.

33. C. A. Grimes, E. C Dickey, and M. V Pishko (Eds.), Encyclopedia of Sensors, vol. 10, 2006, pp. 1-16.

34. E. Bakker, P. Buhlmann, and E. Pretsch, Chem. Rev. 97 (1997) 3083-3132. 